\title{
The implication of Innovation, Proactivity, Risk Taking, Artistic Orientation, and Financial Literacy on Creative Economy Business Performance During the Pandemic
}

\author{
Suripto
}

Department of Business Administration, Faculty of Social and Political Science, Universitas Lampung, Lampung 35141, Indonesia; suriptob.1969@fisip.unila.ac.id

\begin{abstract}
This study aims to determine the Implication of innovation, proactivity, risk-taking, artistic orientation, and financial literacy on creative economy businesses during the COVID-19 pandemic. This was conducted on 120 creative economy businessmen in Bandar Lampung City, which is a miniature of Indonesia with multiethnic cultures. The results showed innovation is not significant, but proactive attitude, artistic orientation, and financial literacy have a significant implication on the performance of creative economic businesses during the Covid-19 pandemic.
\end{abstract}

Keywords: innovation; proactivity; financial literacy; economy business performance

\section{Introduction}

There are 64.18 million MSME units, where $98.68 \%$ are self-employed microenterprises with a $61 \%$ GDP contribution in 2018 , employment by $97 \%$, and export by $14.7 \%$. Furthermore, $52 \%$ of MSMEs were included in the informal category. According to the study of MSME business recovery (National Development Planning Agency, 2020), the challenges faced by these enterprises due to COVID-19 are financial and nonfinancial problems, as well as Demand and Supply Shocks (Suripto, 2021). The pandemic has made the global economy experience a crisis, which is indicated by negative economic growth. This condition has an impact on the business world, both large, medium, and small scale enterprises. Therefore, to maintain continuity, medium, and small businesses should adapt to facing a pandemic through crisis or risk management (Jalali et al., 2020), (Gunarto et al., 2020), (Petrov \& Petrova, 2021) (Supriyanto et al., 2021). Also, pandemic situations will cause a business crisis, which will threaten the enterprise, and consequently lead to a decline in performance, or even bankruptcy.

Achievement of creative business performance is determined by entrepreneurial and artistic orientation, as well as financial literacy understanding (Rudy, 2019), (Sandberg, 2019). The creative industry emphasizes more on creativity and irrationality, in contrast to the conventional, which emphasizes more on the marketing aspect (Fillis, 2002). Following the economic development, there has been a movement for marketing culture (Ellmeier, 2003). Therefore, in other to survive, the creative industry should consider the business aspect by marketing the culture. In the creative industry, the existence of women businessmen is more creative than men who have dominant innovation aspects (Ruth Eikhof, 2017). Business performance in the creative industry is determined by innovative products, which are driven by a proactive market orientation (Huynh et al., 2019), (Riassy \& Kristinae, 2021). Meanwhile, the achievement of creative industry performance is determined by market-oriented business aspects. Therefore, innovative products should be oriented towards market needs. The performance is determined by the government's role in encouraging an innovative culture in the small and medium enterprises sector (Hanifah et al., 2020). 
The ability to take risks and innovations greatly determine the performance achievement of small and medium enterprises (S. H. Lee et al., 2016), (Jalali et al., 2020). Entrepreneurs will confront uncertain conditions, therefore they should be able to identify and calculate the possibility of not achieving their goals. When a business faces a crisis, an entrepreneur should have the courage to take risks. They need to be proactive and innovative to improve their business performances (B. R. Lee et al., 2018), (Jalali et al., 2020). Therefore, performance achievement in a pandemic period is determined by the entrepreneur's ability to innovate and the courage to take risks. In addition, they should be proactive in seeking business opportunities when the environment is full of uncertainty.

Based on previous studies, it can be concluded that the decline in business performance during the pandemic was caused by financial and non-financial problems, therefore an understanding of financial literacy is important to overcome these challenges. Also, pandemic conditions require entrepreneurs to always be proactive in looking for opportunities to improve their performances by being innovative. Every decision during a pandemic is full of uncertainty, therefore the entrepreneurs' attitude to bravely take risks is needed. Therefore, this study aims to analyze the implication of proactive attitudes, innovation, risk-taking, and creative orientation on business performance in the creative industry during a pandemic. The results are expected to become literature material related to performance achievement in the creative industry during a pandemic or similar conditions. This study is also expected to become literary material in solving the creative industry problems comprehensively related to achievement during a pandemic. This study consists of one introduction, two literature reviews, three methods, four results, and a discussion.

\section{Materials and Methods}

\subsection{Research Method}

Entrepreneurship is a creative activity, hence, the creative economy shares some of the most important features of an entrepreneurial economy. This activity depends on the innovation, vision, and talent of writers, creators as well as artists. Also, development opportunities related to changes in cultural practices require thorough vigilance from creative economy stakeholders. Furthermore, the economy should face high demand uncertainty, because entrepreneurial and artistic creativity, as well as culture, are interrelated (Carayannis, 2020). Innovation can be defined as a business effort to find new products, services, and technological processes through a creative process to generate novel and experimental ideas (Lumpkin \& Dess, 1996). Meanwhile, proactive can be defined as an effort to maintain business by looking for opportunities through the introduction of new brands or products, which can therefore win the competition when the business decrease or is in the maturity stage (Venkatraman, 1989), (Ahman et al., 2021). The entrepreneur's ability in taking risks to implication their business performance (Linton, 2019). Also, unique cultural values will be attached to create products with competitive advantages. This places entrepreneurs with a high creative orientation ability to maintain their businesses (Purnomo \& Purnomo, 2019). Moreover, financial literacy is the ability to make decisions related to means of obtaining and using money (Beal \& Delpachitra, 2003).

\subsection{Research Type}

This is an explanative study using a quantitative approach. An explanative method according to Sugiono (2015) is a study that explains the causal relationship between the variables that implication the hypothesis. The main reason for choosing an explanative study is to propose a hypothesis that will explain the interactive or reciprocal relationship between variables and the extent to which these relationships implication each other. The quantitative approach was used because the data is manifested in the form of numbers and analyzed based on statistical analysis. This was conducted to show the implication of innovation, risk-taking, pro-active, artistic orientation, and financial literacy on the performance of small and medium enterprises in the Creative Economy sector at Bandar Lampung. 


\subsection{Sample}

According to Suripto (2020), the sample is part of the total and the characteristics possessed by the population. Suharsimi (2013) stated that the sample is part or representative of the population examined. In this study, the object was Creative MSE actors in Bandar Lampung. This location was chosen as the sample because the city is a miniature of Indonesia where all ethnic cultures can be found. The study sample was determined using as many as 120 creative SME actors.

\subsection{The Measurement Scale}

The Likert scale was used to measure respondents' attitudes with the classification of strongly agree, agree, quite agree, disagree, and strongly disagree, with the score scale at 5 to 1 .

Testing Results of Research Instruments

Validity Test

A validity test was used to determine the questionnaire validity in collecting data by considering the value of the Pearson correlation coefficient. It was carried out with the bivariate Pearson correlation value where the validity level can be measured by the coefficient value with a significance value. According to table 1, it was shown that every item of the instrument has a significance value of 0.000 . Therefore, the instrument consisting of innovation, proactive, risk-taking, artistic, financial literacy, and performance variables is valid (Suripto,2021).

Reliability Test

A questionnaire is declared reliable when a person's response to a statement is consistent or stable over time. The reliability test in this study was determined using the Alpha formula carried out at the level $=0.05$. The instrument can be said to be reliable when Cronbach's Alpha value is greater than 0.6. Meanwhile, according to table 1 , it was shown that the Cronbach's Alfa value of all variables is greater than 0.6. This means all variables including innovation, proactive, researching, artistic, financial literacy and performance are consistent, therefore it can be used in this study.

Normality Test

The normality test was used to determine whether the regression model has a normal data distribution or not. The criteria for residual data use the normal P-P Plot approach. It can be carried out by scattering the points contained in the image. Provided the distribution of the points is close to or dense on a straight line (diagonal), it can be concluded that the residual data is normally distributed, on the contrary, when the points are away from the line, it is said to be abnormally distributed. The acquisition of normality test results is shown in Figure 1:

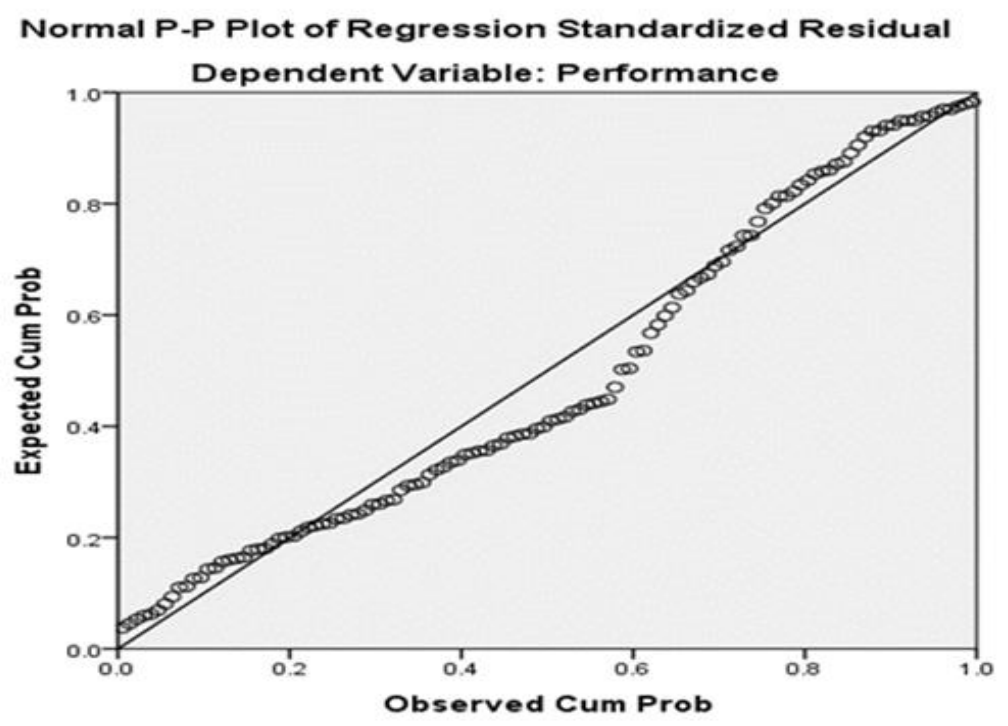


According to Figure 1, it was shown that the distribution of points from the P-P Plot image is relatively close to a straight line (diagonal), therefore it can be concluded that the residual data is normally distributed.

Multicollinearity Test

The multicollinearity test aims to test whether the regression found a correlation between the independent variables. In this study, the techniques used to detect the presence or absence of multicollinearity in the regression model can be seen from the tolerance value and Variance Inflation Factor (VIF). Tolerance values above 0.1 and VIF below 10 showed that there is no multicollinearity among the independent variables. According to the processing results, the multicollinearity test using SPSS 24 obtained the following data: as shown in Table 1:

Table 1. Results of Validity, Reliability, and Multicollinearity Tests

\begin{tabular}{|cccccc|}
\hline Variable & $\begin{array}{c}\text { Cronbach's } \\
\text { Alpha }\end{array}$ & VIP & $\begin{array}{c}\text { Pearson'Corelation } \\
\text { Coefficient }\end{array}$ & Sig & $\begin{array}{c}\text { Number of } \\
\text { items } \\
\text { by variable }\end{array}$ \\
\hline Innovation & 0.818 & 1.007 & 0.792 & 0.000 & 3 \\
\hline Proactive & 0.789 & 2.611 & 0.713 & 0.000 & 3 \\
\hline Risk-taking & 0.784 & 2.535 & 0.725 & 0.000 & 6 \\
\hline Artistic & 0.774 & 2.522 & 0.712 & 0.000 & 4 \\
\hline $\begin{array}{c}\text { Financial } \\
\text { literacy }\end{array}$ & 0.735 & 4.169 & 0.524 & 0.000 & 10 \\
\hline Performance & 0.755 & & 0.610 & 0.000 & 7 \\
\hline
\end{tabular}

According to table 1, it was shown that the three variables have a tolerance value above 0.1 and do not have a VIF value above 10. Therefore, it can be concluded that there is no correlation between the independent variables, in other words, there is no multicollinearity in this study.

\section{Heteroscedasticity Test}

A heteroscedasticity test was used to test for an inequality variance in the regression model from the residuals of one observation to the other. This is carried out by making a scatterplot (distribution flow) between the residuals and the predictive value of the dependent variable which has been standardized. The heteroscedasticity test result is shown on the scatterplot image in Figure 2:

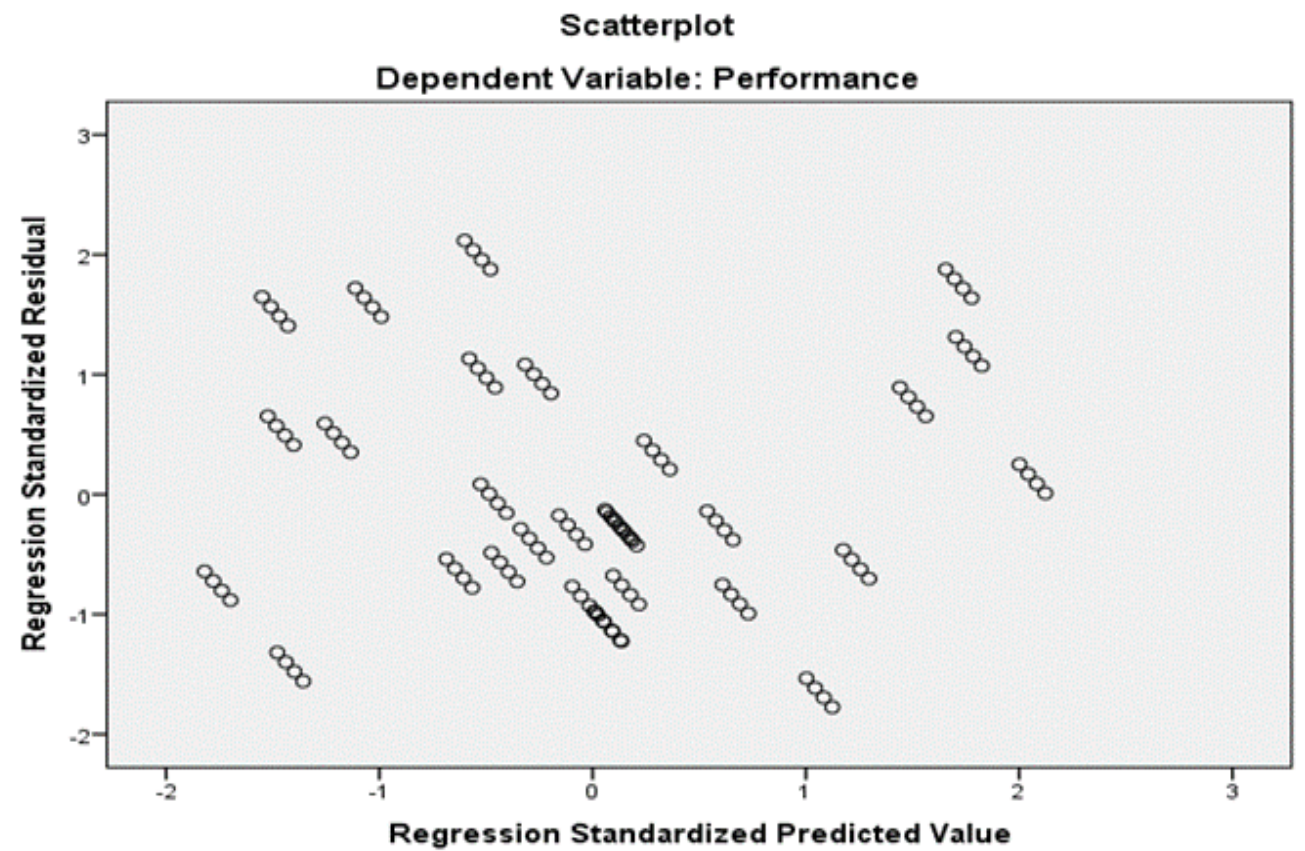


3. Results

3.1. According to the data analysis results of hypothesis testing, it can be concluded that:

\begin{tabular}{|c|c|c|c|c|}
\hline \multicolumn{5}{|c|}{ Hypothesis Results } \\
\hline Hypothesis & $\beta$ & $\mathbf{t}$ & Sig & Test Result \\
\hline $\begin{array}{l}\text { Innovation to performance } \\
\text { Proactive to Performance } \\
\text { Risk-taking to Performance } \\
\text { Artistic to Performance } \\
\text { Financial Literacy to Performance }\end{array}$ & $\begin{array}{l}0.006 \\
0.896 \\
0.380 \\
-894 \\
-240\end{array}$ & $\begin{array}{c}- \\
1.011 \\
6.346 \\
5.759 \\
- \\
6.899 \\
5.843\end{array}$ & $\begin{array}{l}0.314 \\
0.000 \\
0.000 \\
0.000 \\
0.000\end{array}$ & $\begin{array}{l}\text { Rejected } \\
\text { Accepted } \\
\text { Accepted } \\
\text { Accepted } \\
\text { Accepted }\end{array}$ \\
\hline
\end{tabular}

\subsection{Hypothesis Results}

The hypothesis test result of innovation to performance was rejected with a significant value of 0.314 greater than 0.05 .

The hypothesis test result of Proactive to Performance was accepted with a significant value of 0.000 less than 0.05 .

The hypothesis test result of Risk-taking to Performance was accepted with a significant value of 0.000 less than 0.05 .

The hypothesis test result of Artistic to Performance was accepted with a significant value of 0.000 less than 0.05 .

The hypothesis test result of Financial Literacy to Performance was accepted with a significant value of 0.000 less than 0.05 .

\section{Discussion}

\subsection{Achieving performance}

Entrepreneurs will face uncertainty in achieving performance. Measurable uncertainty conditions known as risks will have an impact on business performance. This means the entrepreneurs' courage in taking risks will implication business performance. This study showed risk-taking has a significant implication on business performance, which is related to (Linton, 2019), (Jalali et al., 2020), (Soininen \& Puumalainen, 2012). According to the data processing results, it was shown that innovation does not have a significant implication on business performance. These results are not in line with (Hallak et al., 2018), (Linton, 2019), (Jalali et al., 2020), (Riassy \& Kristinae, 2021). The findings showed that when a pandemic occurs, business conditions experience uncertainty, therefore the market does not consider innovation in making purchasing decisions. This is different under normal conditions, and innovation is very decisive in the purchasing decision-making process. Moreover, the entrepreneurs' understanding of following the financial sector will implication their business performance. Also, an understanding of banking will determine the entrepreneur's in obtaining capital. This study showed understanding financial knowledge will determine business success (Siekei et al., 2013), and creative ideas from an entrepreneur will produce innovative products. Innovative products that are different from others will determine business performance, and creativity is usually associated with the cultural arts where the entrepreneur is located. Furthermore, entrepreneurs in the creative and cultural fields who depend on artistic orientation not only consider innovation but also financial or profitable aspects (Purnomo \& Purnomo, 2019). 


\section{Conclusions}

According to the data processing results, innovation has no significant implication on business performance with a significance value of 0.314 . These findings showed that when a pandemic occurs, business conditions experience uncertainty, therefore the market does not consider innovation in making purchasing decisions. This differs in normal conditions where innovation is very decisive in the purchasing decision-making process.

The entrepreneurs' understanding of regarding financial sector implications their business performance. Also, banking understanding determines the ease of obtaining capital. These findings showed financial knowledge determines business success. Therefore, entrepreneurs in the creative and cultural fields who rely on artistic orientation do not only consider innovation, but also financial aspects.

\section{References}

1. Afonasova, M. A., Panfilova, E. E., Galichkina, M. A., \& Ślusarczyk, B. (2019). Digitalization in economy and innovation: The effect on social and economic processes. Polish Journal of Management Studies, 19(2), 22-32.

https://doi.org/10.17512/pjms.2019.19.2.02

2. Ahman, E., Nurasyiah, A., \& Wulandari, N. S. (2021). http://jssidoi.org/esc/home. 8(3), 604-617.

3. Alexandri, M. B. S. (2021). The Implication of Oil Price Volatility and Price Limit in Indonesia Energy Sub-sector for the Period before and After Covid-19. 11(5), 538-544.

4. Asoba, S. N., \& Patricia, N. M. (2021). Immigrant Entrepreneurship as an Opportunity for Skills Transfer among Craft Entrepreneurs at a Selected Craft Market in Cape Town. Academy of Entrepreneurship Journal, 27(1), 1-7.

5. Beal, D. J., \& Delpachitra, S. B. (2003). Financial Literacy Among Australian University Students. 22(1), 65-78.

6. Carayannis, E. G. (Ed.). (2020). Creative Economy BT - Encyclopedia of Creativity, Invention, Innovation, and Entrepreneurship (p. 428). Springer International Publishing. https://doi.org/10.1007/978-3-319-15347-6_300255

7. Chabani, Z. (2021). The Impact of Entrepreneurial Culture on Economy Competitiveness in the Arab Region. Academy of Entrepreneurship Journal, 27(1), 1-13.

8. Dada, O. (Lola), \& Fogg, H. (2014). Organizational learning, entrepreneurial orientation, and the role of university engagement in SMEs. International Small Business Journal, 34(1), 86-104. https://doi.org/10.1177/0266242614542852

9. Dansai, P., Keeratipibul, S., Anuntavoranich, P., Wiriyapanit, M., \& Siripanwattana, W. (2021). Factors Affecting the Effectiveness of Innovative Tools for Food Safety Management: A Case Study of Hotel Industries in Thailand. Academy of Entrepreneurship Journal, 27(1), 1-12.

10. Elias G. Carayannis. (2020). Encyclopedia of Creativity, Invention, Innovation, and Entrepreneurship (U. Washington, DC (Ed.)).

11. Ellmeier, A. (2003). Cultural entrepreneurialism: on the changing relationship between the arts, culture, and employment1. International Journal of Cultural Policy, 9(1), 3-16. https://doi.org/10.1080/1028663032000069158a

12. Fillis, I. (2002). Small Firm Marketing Theory and Practice: Insights From The Outside. Journal of Research in Marketing and Entrepreneurship, 4, 134-157. https://doi.org/10.1108/14715200280001469

13. Gunarto, T., Azhar, R., Tresiana, N., Supriyanto, \& Ahadiat, A. (2020). An accurate estimated model of volatility crude oil price. International Journal of Energy Economics and Policy, 10(5), 228-233. https://doi.org/10.32479/ijeep.9513

14. Hallak, R., Assaker, G., Connor, P. O., \& Lee, C. (2018). Journal of Retailing and Consumer Services Firm performance in the upscale restaurant sector : The e ff ects of resilience, creative self-e fi cacy, innovation, and industry experience. 40(October 2017), 2017-2019.

15. Hanifah, H., Halim, H. A., Ahmad, N. H., \& Vafaei-zadeh, A. (2020). Emanating the key factors of innovation performance : leveraging on the innovation culture among SMEs in Malaysia. 13(4), 559-587. https://doi.org/10.1108/JABS-04-2018$\underline{0130}$

16. Huynh, T., Duong, M. H., Phan, T. T., Van Do, T., Do, T. T. T., \& Nguyen, K. T. (2019). Team dynamics, leadership, and employee proactivity of Vietnamese firms. Journal of Open Innovation: Technology, Market, and Complexity, 5(1). https://doi.org/10.3390/joitmc5010016

17. Issues, S. (2021). http://jssidoi.org/esc/home. 8(3), 527-544.

18. Jalali, A., Jaafar, M., \& Ramayah, T. (2020). Organization-stakeholder relationship and performance of Iranian SMEs. 13(3), 417-436. https://doi.org/10.1108/IMEFM-11-2018-0407

19. Kedarya, T., Cohen, R. S., \& Elalouf, A. (2021). Calculating Entrepreneurial Reputation Risk in Financial Institutions. Academy of Entrepreneurship Journal, 27(1), 1-11.

20. Lee, K.-J., Lu, S.-L., \& Shih, Y. (2018). Contagion Effect of Natural Disaster and Financial Crisis Events on International Stock Markets. Journal of Risk and Financial Management, 11(2), 16. https://doi.org/10.3390/jrfm11020016

21. Lee, S. H., Workman, J. E., \& Jung, K. (2016). Brand relationships and risk: Implication of risk avoidance and gender on brand consumption. Journal of Open Innovation: Technology, Market, and Complexity, 2(3). https://doi.org/10.1186/s40852-0160041-0

22. Linton, G. (2019). proaktif dalam startup : studi kasus dan pengembangan konseptual. 5.

23. Lumpkin, G. T., \& Dess, G. G. (1996) Lumpkin, G.T. and Dess, G.G. (1996), “Clarifying the entrepreneurial orientation construct and linking it to performance", Academy of Management Review, Vol. 21 No. 1, pp. 135-172.

24. Okręglicka, M., Mynarzová, M., \& Kaňa, R. (2015). Business process maturity in small and medium-sized enterprises. Polish Journal of Management Studies, 12(1), 121-131.

25. Petrov, A. I., \& Petrova, D. A. (2021). Open business model of COVID-19 transformation of an urban public transport system: The experience of a large Russian city. Journal of Open Innovation: Technology, Market, and Complexity, 7(3). 
https://doi.org/10.3390/joitmc7030171

26. Purnomo, B. R., \& Purnomo, B. R. (2019). Artistic orientation , fi nancial literacy and entrepreneurial performance. https://doi.org/10.1108/JEC-09-2018-0065

27. Riassy, U., \& Kristinae, V. (2021). Uncertain Supply Chain Management The effect of product innovation on business performance during COVID 19 pandemic. 9, 151-158. https://doi.org/10.5267/j.uscm.2020.10.006

28. Ramos-escobar, E. A. (2021). http://jssidoi.org/esc/home. 8(3).

29. Rudy, P. B. (2019). Artistic orientation, financial literacy, and entrepreneurial performance. Journal of Enterprising Communities: People and Places in the Global Economy, 13(1/2), 105-128. https://doi.org/10.1108/JEC-09-2018-0065

30. Ruth Eikhof, D. (2017). Analyzing decisions on diversity and opportunity in the cultural and creative industries: A new framework. Organization, 24(3), 289-307. https://doi.org/10.1177/1350508416687768

31. Sandberg, B. (2019). Art hacking for business innovation: An exploratory case study on applied artistic strategies. Journal of Open Innovation: Technology, Market, and Complexity, 5(1). https://doi.org/10.3390/joitmc5010020

32. Siekei, J., Wagoki, J., \& Kalio, A. (2013). An Assessment of the role of financial literacy on Performance of Small and Micro Enterprises : Case of Equity Group Foundation Training Program on SMEs in Njoro District, Kenya. 1(7), 250-261.

33. Soininen, J., \& Puumalainen, K. (2012). The impact of the global economic crisis on SMEs : Does entrepreneurial orientation matter? June 2014. https://doi.org/10.1108/01409171211272660

34. Supriyanto, S., Suripto, S., Sugiono, A., \& Sari, P. I. (2021). Impact of Oil Prices and Stock Returns: Evidence of Oil and Gas Mining Companies in Indonesia During the Covid-19 Period. International Journal of Energy Economics and Policy, 11(4), 312-318. https://doi.org/10.32479/ijeep.11290

35. Suripto, S., Supriyanto, S., \& Putri Irmala Sari, P. I. S. (2021). Metode Statistika Bisnis.

36. Suripto, S., \& Supriyanto, S. (2021). Characteristics of banks as determinants of profit management for Islamic and conventional banks in ASEAN. Accounting, 7(5), 1179-1188.

37. Suripto, S. (2021). The Effect of the COVID-19 Pandemic on Stock Prices with the Event Window Approach : A Case Study of State Gas Companies, in the Energy Sector. International Journal of Energy Economics and Policy, 11(3), 155-162. https://www.econjournals.com/index.php/ijeep/article/view/10999/5799

38. Waliszewski, K., \& Warchlewska, A. (2021). How we can benefit from personal finance management applications during the COVID-19 pandemic? The Polish case. Entrepreneurship and Sustainability Issues, 8(3), 681-699. https://doi.org/10.9770/jesi.2021.8.3(42). 